\title{
Physiological responses and growth performance of growing Barki Ewe lambs fed treated Jojoba meal with Aspergllus orgyzae under semi-arid conditions
}

\author{
Reda, A. Abd-Elazem* \\ *Corresponding Author: \\ Reda, A. Abd-Elazem \\ Animal and poultry physiology department, Desert Research Center, Cairo, Egypt \\ Email: reda.drc@Gmail.com
}

Animal and poultry physiology department, Animal and poultry Division, Desert Research Center, Cairo, Egypt

Received date: 23 January 2019 Accepted date 12 August 2019 Online date: 4 September 2019.

Copyright: (C) 2018 Reda, A. Abd-Elazem, This is an open-access article distributed under the terms of the Creative Commons Attribution License, which permits unrestricted use, distribution, and reproduction in any medium, provided the original author and source are credited.

\begin{abstract}
This study aimed at investigating the effect of feeding treated Jojoba meal with Aspergllus orgyzae Fk-923 fungus (TJM) on some hematological, blood biochemicals, thyroid hormones pattern and growth performance of growing female Barki lambs. Thirty Six of growing Barki ewe lambs (90 days of age with average live body weight of $15.41 \pm 0.71 \mathrm{~kg}$ ) were used for 210 days. Lambs were randomly divided into three equal groups (12 ewe lambs of each). The $1^{\text {st }}$ group (G1) served as control and fed the basal diet, while the $2^{\text {nd }}$ and $3^{\text {rd }}$ groups (G2 and G3) were fed diet contained 7 and $14 \%$ TJM, respectively as a replacement of cotton seed meal. Results revealed that Jojoba treated meal improved hematological parameters of lambs, especially red blood cells count and hemoglobin concentration. Total serum proteins and globulin concentrations increased significantly in female lambs of TJM groups, while albumin concentration insignificantly decreased. Animals of G2 recorded the highest value of glucose (51.28 mg/dl) followed by those of G3 (47.48 mg/dl), while animal of control group recorded the lowest value (43.07 mg/dl). However, cholesterol concentration recorded the highest $(\mathrm{P}<0.05)$ value by $\mathrm{G} 1$ than those of TJM groups with values being $99.78,91.85$ and $91.22 \mathrm{mg} / \mathrm{dl}$ for G1, G2 and G3, respectively. In accordance, total lipids, high density lipoprotein cholesterol and low density lipoprotein cholesterol were significantly higher in control group than those in TJM groups. On the other hand, Jojoba meal did not affect liver enzymes and blood urea, while creatinine decreased significantly. Triiodothyronine hormone insignificantly increased in TJM groups than the control one, while Tetraiodothyronine significantly increased in G2 than other groups. Daily gain and final body weight increased significantly in ewe lambs of TJM groups than those of control group. It could be concluded that treated Jojoba meal with AspergllusorgyzaeFk-923 fungus can be used in growing lambs' ration under semi-arid conditions of Egypt without critical adverse effects on their hemato-biochemical responses or metabolic rate.
\end{abstract}

Kay words: Jojoba meal, growth performance, blood parameters, thyroid hormones

\section{INTRODUCTION}

Sheep and goats have economic importance in Egypt. A wide variety of purposes, especially as a source of meat, wool and skin. The productivity of sheep and goats was reported to be low, particularly under desert conditions, due to a number of factors as feed shortage either in quality or quantity (Tsedeke, 2007). Blood biochemical and hematological profile is an essential index of the physiological and health state of the animal. Esonus et al. (2001) stated that hematological profile reflects the physiological responsiveness of the animal to its internal and external environments including feeds and feeding.

The lake of sufficient feed to meet the nutritional requirements of the existing animal population is one of the most critical problems of animal production under Egyptian deserts. High feeding costs result from the shortage of protein sources used for animal feed. Thus, there is a need to estimate alternative protein sources to overcome such shortage problem. Consequently, many attempts have been made for using feed additives or agriculture byproducts (Ismaiel et al., 2010) that are added to animal feed to improve their nutritive value, increasing growth rate and better feed conversion efficiency (Pluske, 2013).

Jojoba (Simmondsia chinensis) is a shrub belonging to the Simmondsiaceae family which can be used as antraditional protein source in the animal diets. Several advantages are favouring Jojoba seed to be grown in newly reclaimed soils in Egypt such as limited water requirements, high seed yield and relatively high oil content (Abdou, 2018). Jojoba meal, the by-product, is obtained from the oil extraction of the seeds contains from 26 to $33 \%$ crude protein (Nasser et al., 2007) and would increase the economic value of this crop if it used as a feed ingredient. Jojoba meal, as a by-product of Jojoba seeds, is a promising feedstuff after being detoxified (Motawe, 2006). El-Damrawy et al. (2015) found that biological treatment of Jojoba meal by Lactobacillus acidophilus and Tricoderma ressiemay eliminate the anti-nutritional factors. Moreover, Jojoba meal contains several beneficial compounds, such as phytic acid and polyphenols, which shows antioxidant and anti-cancer activity (Wiseman and Price, 1987). 
However, there is a few published data on the response of sheep to the diet containing Jojoba meal. Therefore, the aim of this study was initiated to determine the relative acceptability of diets containing $7 \%$ or $14 \%$ treated Jojoba meal with Aspergllus orgyzae and its effects on hematological, biochemical and growth performance of growing female Barki lambs under semi-arid conditions of Egypt.

\section{MATERIALS AND METHODS}

This study was carried out at Mary out Research Station that belongs to the Desert Research Center and located at $35 \mathrm{Km}$ south-west of Alexandria. A total number of 36 growing female lambs with an average live body weight of $15.41 \pm 0.71 \mathrm{~kg}$ and 90 days of age were used in a feeding trial for 210 days. Lambs were randomly divided into three equal groups; according to their live body weights (12 lambs of each). The animal was kept in semi-open pens roofed with wood and was clinically healthy and free from internal and external parasites.

The detailed procedure of preparing treated Jojoba meal with Aspergllus orgyzae Fk-923 fungus and its replacement to cottonseed in the concentrate feed mixture was explained in previous nutritional study on the same experimental animals (Abdou, R. Ahlam, 2018). Jojoba meal (JM) was supplied by the Egyptian Natural oil Company. The $1^{\text {st }}$ group (G1) served as control and fed the basal diet, while the $2^{\text {nd }}$ and $3^{\text {rd }}$ group (G2 and G3) were fed diets contained treated Jojoba meal (TJM) at level of 7 and $14 \%$ as a replacement of cottonseed meal, respectively (Table 1). All groups were offered berssem (Trifolium alexandrnum) hay as a source of roughage and the freshwater was available all times. Berseem hay and concentrate feed mixture were offered to cover animals' nutrient requirements during the experimental period according to Kearl (1982). The experimental lambs were individually weighed bi-weekly and the number of rations was adjusted depending on the live body weight changes till the end of the experiment. The proximate analysis of different rations were determined by the standard AOAC (2005), while nitrogen-free extract (NFE) was determined by the calculated difference. The data of chemical analysis of the experimental ration, roughage, untreated jojoba meal (UJM) and treated jojoba meal with fungi (TJM) were represented in Table (2).

Table (1). Feed ingredients (\%) of experimental concentrate feed mixtures (\% on dry matter basis)

\begin{tabular}{lccc}
\hline Items & G1 & G2 & G3 \\
\hline Cotton seed & 20 & 13 & 6 \\
Jojoba meal treated with fungi & 0 & 7 & 14 \\
Yellow corn & 53 & 53 & 53 \\
Soybean meal & 10 & 10 & 10 \\
Wheat bran & 10 & 10 & 10 \\
Molasses & 4 & 4 & 4 \\
Salt & 1.2 & 1.2 & 1.2 \\
Limestone & 1.5 & 1.5 & 1.5 \\
Mineral Premix & 0.3 & 0.3 & 0.3 \\
\hline
\end{tabular}

G1: Control: concentrate feed mixture (CFM), G2: CFM containing 7\% treated Jojoba meal with fungi, G3: CFM containing 14\% treated Jojoba meal with fungi

Table 2. Chemical analysis and concentration of the experimental rations, UJM, TJM and roughage \%) on dry matter basis)

\begin{tabular}{lcccccc}
\hline Items & DM & Ash & OM & CP & CF & EE \\
\hline G1 & 92.75 & 6.20 & 93.8 & 16.70 & 6.52 & 4.51 \\
G2 & 92.71 & 6.88 & 93.12 & 17.24 & 5.69 & 4.26 \\
G3 & 93.81 & 6.46 & 93.54 & 17.40 & 4.48 & 4.39 \\
Berseem hay & 89.76 & 14.75 & 85.25 & 15.32 & 28.51 & 1.47 \\
UJM & 93.86 & 3.09 & 96.91 & 27.78 & 9.56 & 10.19 \\
TJM & 90.72 & 5.88 & 94.12 & 28.45 & 6.97 \\
\hline
\end{tabular}

DM: dry matter, OM: organic matter, CP: crude protein, CF: crude fibre, EE: ether extract. G1: Control: concentrate feed mixture (CFM), G2: CFM containing 7\% treated Jojoba meal with fungi, G3: CFM containing 14\% treated Jojoba meal with fungi, UJM: untreated Jojoba meal, TJM: treated Jojoba meal with fungi.

Blood samples from lambs of each group were biweekly collected through vein puncture (using clinical needle) into a tube containing EDTA to examine immediately hematological parameters using blood cell counter (Hemavet $950 \mathrm{~F}$, Drew Scientific, Dallas, TX, USA). Hematological parameters included red blood cells count (RBC's $\times 10^{6}$ cells/ul), white blood cells $\left(\right.$ WBC's $\times 10^{3}$ cells/ul), hemoglobin concentration $(\mathrm{Hb}, \mathrm{g} / \mathrm{dl})$ and packed cell volume $(\mathrm{PCV} \%)$. Blood samples were centrifuged at $3000 \mathrm{rpm}$ for 20 minutes for the separation of plasma and kept at $-20{ }^{\circ} \mathrm{C}$ until further analysis. Blood biochemical parameters were determined for total proteins (TP) albumin (Alb), total cholesterol, and high-density lipoprotein cholesterol (HDLc) concentrations 
using commercial colorimetric kits supplied by Biodiagnostic Company for Laboratory Services. While, globulin (Glb), albumin/globulin ratio (A/G) and low-density lipoprotein cholesterol (LDHc) were calculated. Aspartate and alanine aminotransferases (AST and ALT), total lipids (TL), triglycerides, urea, and creatinine were determined by colorimetric test kits supplied by Diamond Diagnostic Company for Laboratory Services. An automatic spectrophotometer was used during the current study (Model 6405 Brand Jenway, City Chelmsford, Essex Country England). Thyroid hormones $\left(\mathrm{T}_{3}\right.$ and $\mathrm{T}_{4}$ ) were measured by ELISA method using Immunospec kits supplied by Immunospec Corporation, 7018 Owensmouth Ave. Suite 103 Canoga Park, CA 91303, USA.

\section{Statistical analysis:}

Data were analyzed by the least square analysis of variance for repeated measurements using the General Linear Model Procedure (SAS, 2004). Significant differences among means were tested using Duncan multiple range test (Duncan, 1955). However, weeks did not significantly affect any of the blood parameters. Accordingly, tables containing blood parameters displayed only the effect of treatment.

\section{RESULTS AND DISCUSSION}

\section{Hematological parameters:}

Female Barki lambs that fed ration contained 14\% Jojoba meal (G3) increased significantly total WBC's count, RBC's count, $\mathrm{Hb}$ concentration and PCV\% by 40.3, 37.4, 30.7 and 8.1\%, respectively, as compared to control lambs (in G1) (Table 3). This finding showed that feeding ration containing 14\% TJM improved animal health and their nutritional status.

Female lambs fed 7\% TJM (G2) recorded significantly higher $\mathrm{Hb}$ concentration by $23.1 \%$ as compared to control ones. On the other hand, WBC's and RBC's of lambs in G3 were increased $(\mathrm{P}<0.05)$ by 21.3 and $26.5 \%$, respectively, as compared to their counterpart lambs in G2.

Esonus et al. (2001) stated that hematological profile reflects the physiological responsiveness of the animal to its internal and external environments. The effect of various feeds including unconventional sources on hematological profile of livestock was stated (Emenalom and Udebibie, 1998). In the present study, the improvement of hematological parameters might be due to the fact that body weight of those animals were increased their body weight which demands excessive quantity of erythrocyte cell count to obtain more quantity of oxygen (Shams Al-Dain and Jarjeis 2015). In addition, these increases in RBC's, WBC's and $\mathrm{Hb}$ might be attributed to the fact that TJM have high contents of amino acids, vitamins (particularly, vitamin C, E and A), phytic acid and polyphenols (Wiseman and Price, 1987). These contents are considered antioxidants that remove free radicals, activate antioxidant enzymes and inhibit oxidases, hence preventing the reduction of oxygen consumption in growing lambs (Anderson, 1981; Jaffe, 1984 and Ibrahim et al., 2014).

Table (3). Overall means of hematological parameters of lambs as affected by Jojoba supplementation

\begin{tabular}{|c|c|c|c|c|}
\hline Traits & G1 & G2 & G3 & $\begin{array}{c}\text { Treatment } \\
\pm \mathrm{SE}\end{array}$ \\
\hline White blood cells (X $\left.10^{3} / \mathrm{ml}\right)$ & $8.35^{\mathrm{b}}$ & $9.66^{b}$ & $11.72^{\mathrm{a}}$ & $0.61 *$ \\
\hline Red blood cells $\left(X 10^{6} / \mathrm{ml}\right)$ & $7.08^{\mathrm{b}}$ & $7.69^{\mathrm{b}}$ & $9.73^{\mathrm{a}}$ & $0.41 *$ \\
\hline Hemoglobin (g/dl) & $7.93^{\mathrm{b}}$ & $9.76^{\mathrm{a}}$ & $10.37^{\mathrm{a}}$ & $0.23 *$ \\
\hline Packed cell volume (\%) & $31.33^{\mathrm{b}}$ & $33.46^{\mathrm{ab}}$ & $33.86^{\mathrm{a}}$ & $0.83 *$ \\
\hline
\end{tabular}

G1: control lambs fed (CFM+ berseem hay), G2: lambs fed CFM containing 7\% treated Jojoba meal with fungus+ berseem hay, G3: lambs fed CFM containing $14 \%$ treated Jojoba meal with fungus+ berseem hay. \pm SE $=$ standard error, $*=$ significant at $\mathrm{P}<0.05,{ }^{\mathrm{a}, \mathrm{b}}$ Means bearing different superscripts within the same row are significantly different $(\mathrm{P}<0.05)$.

\section{Total proteins and its fraction:}

Total serum proteins (TP) and globulin $(\mathrm{Glb})$ concentrations in female Barki lambs were significantly increased by using TJM, while Albumin (Alb) was not affected (Table 4). This meant that the increase in TP was mainly due to increased Glb level. This result refers to the positive effect of JM diet on the immune response that might be related to the role of JM in the metabolism of amino acids via enhancing the protein synthesis enzymes (Shrestha et al., 2002). However, the increase in Glb did not affect the levels of Alb. Total proteins of all experimental groups were nearly within the normal range being 5-8 g/dl (Mahmoud, 2013), while albumin values were higher than those reported by Ghooneem (2010), which ranged between 2.53 to $2.95 \mathrm{~g} / \mathrm{dl}$. It can be concluded that TJM enhance immune system without any adverse effect on Alb and plasma osmolality.

\section{Table (4). Overall means of total protein and its fractions parameters of lambs as affected by Jojoba supplementation}




\begin{tabular}{|c|c|c|c|c|}
\hline Traits & G1 & G2 & G3 & $\begin{array}{c}\text { Treatment } \\
\pm S E\end{array}$ \\
\hline Total protein (g/dl) & $5.32^{b}$ & $6.12^{\mathrm{a}}$ & $5.93^{\mathrm{ab}}$ & $0.21^{*}$ \\
\hline Albumin (g/dl) & 3.42 & 3.15 & 3.26 & 0.25 \\
\hline Globulin (g/dl) & $1.90^{\mathrm{b}}$ & $2.97^{\mathrm{a}}$ & $2.67^{\mathrm{a}}$ & $0.22 *$ \\
\hline Albumin/Globulin & $1.80^{\mathrm{a}}$ & $1.06^{\mathrm{ab}}$ & $1.22^{\mathrm{b}}$ & $0.29 *$ \\
\hline
\end{tabular}

G1: control group fed (CFM+ berseem hay), G2: group fed CFM containing 7\% treated Jojoba meal with fungus+ berseem hay, G3: group fed CFM containing $14 \%$ treated Jojoba meal with fungus+ berseem hay. $\pm \mathrm{SE}=$ standard error, ${ }^{\mathrm{a}, \mathrm{b}}$ Means bearing different superscripts within the same row are significantly different $(\mathrm{P}<0.05)$.

\section{Glucose and Lipids profile:}

Serum Glu concentrations increased $(\mathrm{P}<0.05)$ in all treated female lambs with TJM when compared to the control ones (Table 5). Female lambs of G2 recorded the highest value of Glu (51.28 mg/dl) followed by those in G3 (47.48 mg/dl), while control lambs recorded the lowest value $(43.07 \mathrm{mg} / \mathrm{dl})$. On the other side, cholesterol concentration recorded the highest $(\mathrm{P}<0.05)$ value in control lambs with the values being $99.78,91.85$ and $91.22 \mathrm{mg} / \mathrm{dl}$ for G1, G2 and G3, respectively. A similar trend was also noticed in triglyceride $(154.55,147.30$ and $145.57 \mathrm{mg} / \mathrm{dl})$ for $\mathrm{G} 1, \mathrm{G} 2$ and $\mathrm{G} 3$, respectively.

Table (5). Overall means of glucose and lipid profile of lambs as affected by Jojoba supplementation

\begin{tabular}{lcccc} 
Traits & \multirow{2}{*}{ G1 } & G2 & G3 & Treatment \\
Glucose (mg/dl) & $43.07^{\mathrm{b}}$ & $51.28 \mathrm{a}$ & $47.48^{\mathrm{ab}}$ & 1.67 \\
Total lipids (mg/dl) & $2.45^{\mathrm{a}}$ & $2.15^{\mathrm{ab}}$ & $1.82^{\mathrm{b}}$ & 0.11 \\
Cholesterol (mg/dl) & $99.78^{\mathrm{a}}$ & $91.85^{\mathrm{b}}$ & $91.22^{\mathrm{b}}$ & 2.76 \\
Triglycerides (mg/dl) & 154.55 & 147.30 & 145.57 & 5.41 \\
LDL (mg/dl) & $55.88^{\mathrm{a}}$ & $41.40^{\mathrm{b}}$ & $38.66^{\mathrm{b}}$ & 4.58 \\
HDL (mg/dl) & $50.30^{\mathrm{a}}$ & $38.26^{\mathrm{ab}}$ & $34.65^{\mathrm{b}}$ & 4.24 \\
\hline
\end{tabular}

G1: control group fed (CFM+ berseem hay), G2: group fed CFM containing 7\% treated Jojoba meal with fungus+ berseem hay, G3: group fed CFM containing $14 \%$ treated Jojoba meal with fungus+ berseem hay.

$\pm \mathrm{SE}=$ standard error, ${ }^{\mathrm{a}, \mathrm{b}}$ Means bearing different superscripts within the same row are significantly different $(\mathrm{P}<0.05)$.

These results agreed with those reported in rabbits by Khayyal et al. (2009) and El-Adawy et al., (2013) who found that rabbits fed control diet recorded a significant increase in cholesterol and triglyceride levels as compared to rabbits fed diets contain different levels of JM treated with Lactobacillus acidophilus. These results probably due to the effect of biological treatment in reducing the concentration of saturated fatty acids and improving the unsaturated fatty acids in JM. Otherwise, tannin and saponin might contribute to the present results since Matsura (2001) and Francis et al. (2002) reported that saponin from different dietary sources caused low serum cholesterol levels in a variety of animals. Moreover, saponin causes a delaying of intestinal absorption of dietary fat by inhibiting pancreatic lipase activity (Han et al., 2000).

In contrary, El-Kady et al. (2008) recorded that lambs fed 30\% raw JM increased the concentrations of plasma cholesterol and triglyceride $(\mathrm{P}<0.01)$ by 46.00 and $26.96 \%$, respectively versus control. However, El-Shennawy (2003) found that there were no significant differences of plasma cholesterol and triglyceride concentrations among groups of rats fed untreated and treated JM with irradiation, heat, microwave or fermentation as compared to the control.

Plasma total lipids (TL), high-density lipoprotein (HDLc) and low-density lipoprotein (LDLc) were significantly decreased $(\mathrm{P}<0.01)$ in lambs fed TJM (G2 and G3) as compared to the lambs in control group (Table 5). It seemed that feeding TJM with the levels of 7 and $14 \%$ as a replacement of cotton seeds in concentrate mixture enhanced protein syntheses on account of lipids due to the high amino acids content in Jojoba seeds. Wiseman and Price (1987) stated that TJM have high contents of amino acids, vitamins (C, E and A), phytic acid and polyphenols.

The present results were contrasted with those reported by Flo et al. (1999) and Sobhy et al. (2003) who found elevation in lipid profile in lambs fed high levels of JM in the ration (30\%). These discrepancy in results might be attributed to the high level of JM they used. From another point of view, Rose et al. (1994) attributed the elevation of lipids in racing camels fed high level of JM to mobilization of fatty acids from fat depots in response to the release of cortisol due to nutrition stress.

\section{Liver and kidney functions:}

Liver enzymes are used to assess liver damage (Mahgoub et al. 2008). Jojoba meal did not affect liver enzymes concentration among the experimental groups with the values being 21.74, 20.02 and 20.26 IU/L for ALT and 20.61, 18.75 and $20.30 \mathrm{IU} / \mathrm{L}$ for AST in lambs of G1, G2 and G3, respectively (Table 6). The obtained values for both enzymes were within the normal range according to Kahn et al. (2010). These results are in agreement with those reported by Abdou (2018). While, ElKady et al. (2008) reported that the activity of AST was higher $(\mathrm{P}<0.05)$ in lambs fed the 20 and $30 \%$ JM rations. Alkaline phosphatase (ALP) insignificantly decreased in lambs of TJM groups with values being 168.96, 148.77 and 151.95 IU/L for G1, 
G2 and G3, respectively. The results of liver function might be an indication of the non-toxic action of TJM on the body metabolism of the lambs.

In the present study, there were no significant differences between groups in urea concentrations. Female lambs of control group recorded the highest $(\mathrm{P}<0.05)$ value of creatinine compared to lambs of TJM groups with values being $1.27,1.05$ and $0.93 \mathrm{mg} / \mathrm{dl}$ for G1, G2 and G3, respectively (Table 6). There are contradictory findings regarding the effect of JM on blood urea-N. Manos et al. (1988) recorded a significant decrease in blood urea $-\mathrm{N}$ in lambs fed $10 \%$ JM rations, while Sobhy et al. (2003) reported a significant increase in blood urea- $\mathrm{N}$ in rats fed 3\% and 6\% JM diets. On the other hand, Abdou and El-Essawy (2018) and El-Kady (2008) showed that creatinine concentrations were did not affect in lambs fed diets containing JM. The present results indicated that feeding TJM by 7 or $14 \%$ did not represent stress on either liver or kidney functions of growing female lambs.

Table (6). Overall means of some kidney and liver functions parameters of lambs as affected by Jojoba supplementation

\begin{tabular}{lcccc}
\hline Traits & \multirow{2}{*}{ G1 } & G2 & G3 & \multicolumn{2}{c}{ Treatment } \\
& & 21.74 & 20.26 & 1.62 \\
ALT (IU /L) & 20.61 & 18.75 & 20.30 & 1.59 \\
AST (IU /L) & 33.95 & 33.07 & 31.57 & 1.71 \\
Urea (mg/dl) & $1.27^{\mathrm{a}}$ & $1.05^{\mathrm{ab}}$ & $0.93^{\mathrm{b}}$ & $0.10^{*}$ \\
Creatinine (mg/dl) & & & & \\
\hline
\end{tabular}

G1: control group fed (CFM+ berseem hay), G2: group fed CFM containing 7\% treated Jojoba meal with fungus+ berseem hay, G3: group fed CFM containing $14 \%$ treated Jojoba meal with fungus+ berseem hay. ALT = alanine aminotransferase; AST= aspartate aminotransferase; $\pm \mathrm{SE}=$ treatment standard erro; ${ }^{\mathrm{a}, \mathrm{b}}$ Means bearing different superscripts within the same row are significantly different $(\mathrm{P}<0.05)$.

\section{Thyroid hormones:}

Thyroid hormones have a significant effect on growth and development of animals. These hormones had correlation with the metabolism of protein, carbohydrate, fat and energy (Zanouny et al., 2013). In the present study, overall means of Triiodothyronine hormone $\left(\mathrm{T}_{3}\right)$ of growing female Barki lambs was insignificantly increased in TJM groups than the control one (Table 7). While Tetraiodothyronine hormone $\left(\mathrm{T}_{4}\right)$ was significantly increased in G2 (7\% TJM) than other groups.

These results are in accordance with those reported by Abdou (2018) and Abdou and El-Essawy (2018) that there was no differences in $\mathrm{T}_{3}$ concentrations between lambs fed basal ration (control), with those fed rations containing either untreated or treated Jojoba meal, while they reported an increase in $\mathrm{T}_{4}$ level in lambs fed rations containing TJM.

This increase in the activity of thyroid hormones of lambs of G2 and G3 might vary due to the higher percentage of energy and crude protein in treated Jojoba meal (Table 2) that needed higher level of metabolism. Banerie (1976) explained that increasing $\mathrm{CP}$ and energy content resulting in more balanced rations that have suitable nutritive value.

Table (7). Overall means of hormonal aspects of lambs as affected by Jojoba supplementation

\begin{tabular}{lcccc}
\hline Traits & \multirow{2}{*}{ G1 } & G2 & G3 & Treatment \\
& & & $\mathbf{4}$ SE \\
\hline $\mathbf{T}_{\mathbf{3}}$ (ng/dl) & 0.56 & 0.81 & 0.67 & 0.10 \\
$\mathbf{T}_{\mathbf{4}}$ (ng/d) & $0.12^{\mathrm{b}}$ & $0.19^{\mathrm{a}}$ & $0.08^{\mathrm{b}}$ & $0.01^{*}$ \\
\hline
\end{tabular}

G1: control group fed (CFM+ berseem hay), G2: group fed CFM containing 7\% treated Jojoba meal with fungus+ berseem hay, G3: group fed CFM containing $14 \%$ treated Jojoba meal with fungus+ berseem hay; $\pm \mathrm{SE}=$ treatment standard error, ${ }^{\mathrm{a}, \mathrm{b}}$ Means bearing different superscripts within the same row are significantly different $(\mathrm{P}<0.05)$.

\section{Growth performance:}

During first 5 months of age, there were no differences between control and tested groups (Table 8). From 7 month of age then after, lambs fed TJM started to record higher weighs than the control lambs, but the differences became significant at 10 months of age especially those lambs fed 14\% TJM. These differences reflected the variation in daily gain, These results were in agreement with those reported by Abdou and El-Essawy (2018) who found that body weights of lambs were increased when animals fed diets containing treated JM with bacteria or isopropanol as compared to lambs in control and untreated JM groups. Similarly, Khalel et al. (2008) and El-Kady et al. (2008) found that body weight was increased in animals fed ration contained treated JM. The highest total final body weight and daily gain obtained with feeding TJM diets might be due to increasing CP led to formulate more balanced rations had suitable nutritive value with appropriate contents of energy and DCP for growing lambs as mentioned by Banerje (1976). 


\begin{tabular}{|c|c|c|c|c|}
\hline Traits & G1 & G2 & G3 & $\begin{array}{c}\text { Treatment } \\
\pm \text { SE }\end{array}$ \\
\hline Initial body weight at 3 month of age $(\mathrm{kg})$ & 15.60 & 15.51 & 15.45 & 0.70 \\
\hline Body weight at 5 month of age $(\mathrm{kg})$ & 24.82 & 24.44 & 24.22 & 0.88 \\
\hline Body weight at 7 month of age (kg) & 33.23 & 34.21 & 34.89 & 0.75 \\
\hline Final body weight at 10 months of age $(\mathrm{kg})$ & $34.75^{\mathrm{b}}$ & $35.79^{\mathrm{ab}}$ & $36.91^{\mathrm{a}}$ & $0.89 *$ \\
\hline Average daily gain $(\mathrm{g})$ & $91.1^{\mathrm{b}}$ & $96.5^{\mathrm{ab}}$ & $102.1^{\mathrm{a}}$ & $0.17 *$ \\
\hline Total gain & 19.15 & 20.28 & 21.46 & 0.47 \\
\hline
\end{tabular}

G1: control group fed (CFM+ berseem hay), G2: group fed CFM containing 7\% treated Jojoba meal with fungus+ berseem hay, G3: group fed CFM containing 14\% treated Jojoba meal with fungus+ berseem hay. Total average gain = final body weight initial body weight at 3 months; $\pm \mathrm{SE}=$ treatment standard error, ${ }^{\mathrm{a}, \mathrm{b}}$ Means bearing different superscripts within the same row are significantly different $(\mathrm{P}<0.05)$.

All results indicated the importance of treating Jojoba meals to achieve better growth without any adverse physiological effects. Untreated Jojoba meal (JM) is underutilized because it contains high levels of some anti-nutritional compounds such as simmondsins that have adverse effects on animals (NRC, 1985 and Van Boven et al., 2000). Simmondsins has been identified as the most responsible food intake inhibition and appetite suppression to rodents, rats, dogs, chickens (Lievens et al., 2003) and sheep (Weber and Reid 1975). These results were supported by the suggestion of Flo et al. (1999) who explained that simmondsin might increase brown adipose tissue and metabolic rate by over stimulating thyroid production which cause catabolism and lowers feed efficiency that decreases growth rate. In more explanation Verbiscar et al. (1981) reported that simmondsin is broken its aglycon in the intestinal tract by the intestinal bacteria and the aglycon (or its derivatives) is responsible for the feed intake reduction. In confirmation, Manos et al. (1986) reported that ewes fed 5 or 10\% untreated JM showed lower weight gain than the control ewes. Also, Nasser et al. (2007) found that average daily benefits of Rahmany lambs were decreased as untreated JM percentage increased in their rations. They reported average daily gain of growing lambs to be $136,126,79 \mathrm{and} 64 \mathrm{~g} / \mathrm{h} / \mathrm{d}$, when they fed four concentrate mixtures contained $0 \%, 33 \%, 50 \%$ and $100 \%$ untreated JM as replacement of cottonseed meal, respectively.

\section{CONCLUSION}

It could be concluded that treated Jojoba meal with Aspergllus orgyzae Fk-923 fungus can be used in growing lambs' ration in replacement for cottonseed meal in the ratio of 7 or $14 \%$ without any adverse effects on physiological responses and hemato-biochemical parameters. Moreover, this procedure could enhance growth performance of Barki lambs under semi-arid conditions of Egypt.

\section{REFERENCES}

Abdou, R. Ahlam (2018). Bio-Detoxification of Jojoba Meal by Aspergillus oryzae and impact of its utilization in ewes and lambs' feeding. J. Animal and Poultry Prod., Mansoura Univ., 9 (9): 383 -391.

Abdou R. Ahlam and El-Essawy M. Abeer (2018). Productive Performance of Growing Barki Lambs Fed on Jojoba Meal under Desert Conditions. J. Animal and Poultry Prod., Mansoura Univ., Vol.9 (2): 103 - 113.

Anderson, R. (1981). Ascorbic acid and immune function: Mechanism of immunostimulation, In: Vitamin C (Ascorbic Acid) (Eds. J. N. Counsell \& D. H. Horing), Applied Science Publishers, pp. 249-272.

A.O.A.C. (2005). Official methods of analysis association of Analytical chemists, 16th ed. Washington, DC., USA.

Banerjee, G.C. (1976). A text book of animal husbandry. $4^{\text {th }}$ Ed. Oxford and IBH Publishing Co. New Delhi, $417-418$.

El-Adawy, M.M. Abou-Zeid A.E., Camacho L.M., Salem A.Z.M., Cerrillo-Soto M.A.and El-Rayes T. (2013). Influence of Jojoba Meal Treated with Lactobacillus acidophilus on Digestibility, Carcass Traits and Blood Metabolites in Growing Rabbits. Animal Nutrition and Feed Technology (2013) 13: 423-434.

El-Damrawy, S. Z. ; M. H. El-Deeb and A. A. Khattab (2015). Effect of Treated Biologically Jojoba meal on poultry production: A-Broiler performance. Egyptian J. Nutrition and Feeds, 18 (2): 293-300.

El-Kady, R. I.; Abou-Zeina , H. A. A.; Omer, H. A. A.; Salman, F. M .; Shoukry, M. M. and Ahmed, S. M. (2008). Response of growing Ossimi lambs to diets containing different levels of defatted Jojoba meal. American - Eurasian J. Agric. \& Environ Sci, 4 (1): $34-43$.

El-Shennawy, H.M. 2003.Nutritional and Toxicological Studies on Radiation Detoxification of New Protein Source. PhD Thesis, Faculty of Science, Zagazig University, Sharkya, Egypt.

Emenalom, O.O. and A.B.I. Udedibie, 1998. Effect of dietary raw, cooked, toasted mucunapruriens seeds (velvet bean) on the performance of finisher broilers. Nig. J. Anim. Prod. 25: 115-119.

Esonu, B.O.; O.O. Fmenalom; A.B.I. Udedibie, U. Herbert, C.F. Ekpor, I.C. Okolie; F.C.Iheukwumere, 2001. Performance and blood chemistry of weaner pigs fed raw mucuna (velvet bean). Tropical Animal Production Investigations. 4: 49-54. 
Flo, G.; Vermaut, S.; Van Bovwn, M.; Daenens, P.; Buyse, J.; Decuypere, E.; Kuhu, E. and Cokelaere, M. (1999). Effect of simmondsin on food intake, growth and metabolic variables in lean and obese zucker rats. Br. J. Nutr., 81: 159 - 167.

Francis, G.; Kerem, Z.; Makkar H. P. S. and Klaus Becker. (2002). The biological action of saponins in animal systems: a review. British Journal of Nutrition, 88, 587-605.

Ghooneem, Wafaa, M.A. (2010). Biological Treatment of Some Agricultural and Agroindustrial Residues and Their Effects on Performance of Growing Lambs. Ph.D. Thesis, Fac. of Agric., Cairo Univ. Egypt, 121.

Duncun, D.B. (1955). Multiple range and multiple f tests. Biometrics, 11:1-42.

Han, L.K.; Xu B.J, Kimura Y, Zheng ,Y.N. and Okuda, H. (2000): Platycodi radix affects lipid metabolism in mice with high fat dietinduced obesity. Journal of Nutrition 130, 2760-2764

Ibrahim, N.H., A.S. Morsy and M.E. Ashgan, 2014. Effect of Moringa peregrine seeds on productive performance and hematobiochemical parameters of growing rabbits. Journal of American Science., 10(6): 7-12.

Ismaiel, A.M.; A.H. Elfar and I.I. Abou-Gonema (2010). Effect of tonilisat and roemin w2 supplementation on performants of lambs. World Academy of Sci., Engineering and technology, 47: 11-29.

Jaffe, G.M. (1984). In. Handbook of Vitamins (L. J. Machlin, ed.), pp. 199-244. Dekker, New York.

Kahn, CM, Line, S, Aiello, S (2010). 'The Merck Veterinary Manual.' Whitehouse Station, NJ.

Kearl I. C. (1982):Nutrients requirements in developing countries., Utah Agric. Exp. Stat., Utah State Unviersity, Logan, USA.

Khalel, M. S.; Hassan, A. A.; Shwerab, A. M. and Amany, A. Khayyal. (2008). Feed evaluation of chemically or biologically treated Jojoba meal. Egyptian J. Nutr. And Feeds, 11 (3): 481 - 495.

Khayyal, A.A., Hassan, A.A., Shwerab, A.M., Khalel, M.S. and Salem, A.Z.M. 2009. Effect of feeding diets containing Jojoba meal on growth performance of growing rabbits. Egypt. J. of Nut.and Feeds, 12: 475-489.

Lievens, S.; Flo, G.; Decuypere, E.; Van Bovenc, M. and Cokelaere, M. (2003). Simmondsin: effects on meal patterns and choice behavior in rats, Physiology and Behavior 78 : 669-677.

Mahgoub, O.; KadimI, T.; Tageldin, M. H.; Al-Marzooqi, W. S.; Khalaf, S. Q. and Amnbu Ali, A. (2008). Clinical Profile of sheep fed non- conventional feeds containing phenols and condensed tannins. Small Ruminant Research, 78: 115-22.

Mahmoud A.E.M. (2013). Impact of dietary protein levels on digestibility, blood parameters, insulin like growth factore-1 and growth performance of growing Rahmani lambs. Egypt. J. Nut. and Feeds. 16 (2): 195-202.

Manos, C. G.; Schrnemeeckers, P.J.; Hogue, D. E.; Telford, J. N.; Beerman, D. H.; Babish, J. G.; Blue, J.T.; Shane, B. S. and Lisk, D. J. (1988). Toxicological studies with lambs fed Jojoba meal supplemented rations. J. Agric. Food Chem., 34 : 801 805.

Manos, O. G.; R.J. Schrynemeeckers; D. E. Telford; J.N. Stoew; G.S. Sand; D.H. Beerman; J.G. Babish; J.T. Blue; B.S. Sneha and D.J. Lisk (1986). Toxicological studies with lambs fed Jojoba meal sup-plemented rations. J. Agric. Food Chem., 34: 801-805.

Motawe, H. F. A (2006). Chemical and biological evaluation of Jojoba seeds and Jojoba meal Simmondsiachinensis) in comparison with some other plant protein sources". J. Agric. Sci. Mansoura Univ., 31: 6945-6955.

Matsura, M. (2001). Saponins in garlic as modifiers of the risk of cardiovascular disease. Journal of Nutrition 131, 1000-1005.

Nasser, M. E. A., A. M. El- Waziry, S. M. A Sallam, and S.A.S Mahmoud (2007). Evaluation of Jojoba meal as protein source for sheep. Agric. Res. J. Suez Canal Univ., 7 (3): 1-7.

NRC (National Research Council) (1985). Jojoba: New Crop for Arid Lands, New Material for Industry, National Academy Press, Washington, D.C.

Pluske, J.R. (2013). Feed and feed additives related aspects of gut health and development in weanling pigs. J. of Anim. Sci. and Biotec, 4: 1 .

Rose, R. J.; Evans, D. L.; Henckel, P.; Kinight, K. P.; Cluer, D. and Saltin, B. (1994). Metabolic responses to prolonged exercise in the racing camel. ActaPhysiology., Second Suppl., 617: 49-60.

SAS Institute (2004). Statistical Analysis System, STAT/ user's guide, Release 9.1, SAS Institute, Cary NC. USA.

Shams Al-Dain, QZ and Jarjeis, AA (2015). Evaluation of using some medical herbs seeds feed supplementation and their effects on the activity of some enzymes and hormones on meal Awassi lambs. Kufa Journal For Veterinary Medical Sciences 6, 97108.

Shrestha MK, Peri I, Smirnoff P, Birk Y, Golan-Goldhirsh A.( 2002). Jojoba seed meal proteins associated with proteolytic and protease inhibitor activities. J Agric Food Chem;50:5670-5675.

Sobhy, H. M.; E. A. Mohamed ; M. K. Monsour and G.G. Shehab (2003). Influence of Jojoba meal supplementation on body gain, function of organs, biochemical parameters associated pathological alteration in male rats. Kafr El-Sheikh Vet. Med. J, 1: 961-982.

Tsedeke, K. (2007). Production and marketing of sheep and goats in Alaba, Southern Ethiopia. M.Sc. Thesis, Hawassa. Ethiopia

Van Boven , M.; Busson , R.; Cokelaere, M.M; Flo, G. and Decuypere, E. (2000). 4-Demethyl simmondsin from Simmondsiachinensis, Ind. Crops Prod. 12 (203-208).

Verbiscar, J.A.; Banigan, T.F.; Weber, C.W.; Reid, B.L. and Swingle, R.S. (1981). Detoxification of Jojoba meal by lactobacilli.J. of Agric. Food Chem., 29: 296- 302.

Weber, C. W., and Reid, B. L. (1975). Toxic effects of Simmondsia in growing and reproducing mice.Fed. Proc. 34:226.. Anim. Prod., 8: 517. 
Wiseman, M.O and Price R.L.( 1987). Characterization of protein concentrates of Jojoba (Simmondsiachinensis) meal. Cereal Chem;64:91-3.

Zanouny, A, Abd-el-Moty, A, El-Barody, M, Sallam, M, Abd-el-Hakeam, A (2013). Effect of supplementation with Nigella sativa seeds on some blood metabolites and reproductive performance of Ossimi male lambs. Egyptian Journal of Sheep Goat Science8, 47-56. 